\title{
SURGICAL TREATMENT OF THE
} NON-COMPLICATED

\section{GASTROESOPHAGEAL REFLUX. Fundoplication without division of the short gastric vessels}

\author{
Valter Nilton FELIX, Ioshiaki YOGI, Marcos PERINI, \\ Rodrigo ECHEVERRIA and Cristiano BERNARDI
}

\begin{abstract}
Background - There is today a significant greater number of laparoscopic antireflux procedures for the surgical treatment of gastroesophageal reflux disease and there are yet controversies about the necessity of division of the short gastric vessels and full mobilization of the gastric fundus to perform an adequate fundoplication. Aim - To verify the results of the surgical treatment of non-complicated gastroesophageal reflux disease performing Rossetti modification of the Nissen fundoplication. Patients and Methods - Fourteen patients were operated consecutively and prospectively (mean age 44.07 years); all had erosive esophagitis without Barrett's endoscopic signals (grade 3, Savary-Miller) and they were submitted to the Rossetti modification of the Nissen fundoplication. Endoscopy, esophageal manometry and pHmetry were performed before the procedure and around 18 months postoperatively. Results - There was no morbidity, transient dysphagia average was 18.42 days; there was no register of dehiscence or displacement of the fundoplication and only one patient revealed a light esophagitis at postoperative endoscopy; the others presented a normal endoscopic view of the distal esophagus. All noticed a marked improvement of preoperative symptoms. Lower esophageal sphincter pressure changed from $5.82 \mathrm{~mm} \mathrm{Hg}$ (preoperative mean) to $12 \mathrm{~mm} \mathrm{Hg}$ (postoperative mean); lower esophageal sphincter relaxing pressure, from $0.38 \mathrm{~mm} \mathrm{Hg} \mathrm{to} 5.24 \mathrm{~mm} \mathrm{Hg}$ and DeMeester score, from 16.75 to 0.8. Conclusion - Rossetti procedure (fundoplication without division of the short gastric vessels) is an effective surgical method to treat gastroesophageal reflux disease.
\end{abstract}

HEADINGS - Gastroesophageal reflux, surgery. Esophagogastric junction, surgery. Fundoplication.

\section{INTRODUCTION}

Gastroesophageal reflux disease (GERD) has manifestations as pyrosis, dysphagia, odynophagia, early satiety and chronic cough or hoarseness and can causes strictures, Barrett's esophagus and cancer.

Diagnosis is based on patient history, a barium swallow, endoscopy and $\mathrm{pH}$ monitoring. Treatment is individualized, using clinical measures or surgery.

GERD is the most common disease of the esophagus, affecting around $30 \%$ of general population. It has be found in about $50 \%$ of patients with non-cardiac chest pain ${ }^{(7,10)}$,
$75 \%$ of patients with chronic hoarseness, and between $70 \%$ and $80 \%$ of patients with asthma ${ }^{(10)}$.

Nearly all cases of esophageal adenocarcinoma develop in Barrett's esophagus associated with intestinal metaplasia ${ }^{(16)}$, result of chronic recurrent reflux causing erosion and ulceration of the distal squamous mucosa, replaced with metaplastic columnar epithelium.

Reflux episodes in GERD may be described as failure of gastroesophageal defense mechanisms to prevent the retrograde flux into the esophagus.

Defense mechanisms to protect against reflux include anatomic integrity of the esophagogastric junction (EGJ), the 
lower esophageal sphincter (LES) and esophageal clearance, achieved by means of gravity, saliva and esophageal peristalsis.

Intermittent or sustained impairment of LES function is considered the most common cause of GERD. Reflux in a sleeping patient often results in prolonged exposure of the esophagus to reflux because two main clearance mechanisms (peristalsis and gravity) are impaired.

Pyrosis is the classic symptom, but GERD may also presents with one or more symptoms that appear unrelated to the GI tract, including atypical chest pain, chronic cough, bronchospasm or hoarseness.

Several diagnostic tests are available. A barium swallow is the simplest, but the least sensitive test. Endoscopy is the best study for the diagnosis and evaluation of reflux esophagitis or other complications of GERD, such as stricture or Barrett's esophagus. Biopsy specimens can be obtained and strictures can be dilated.

The 24-hour ambulatory $\mathrm{pH}$ monitoring detects quantitatively the reflux and can establish positive symptom association. Some authors suggest that all patients who are being considered for fundoplication surgery should have preoperative $\mathrm{pH}$ monitoring ${ }^{(9)}$.

Esophageal manometry is useful for detecting LES incompetence. The test should be performed in all dysphagic patients who are candidates for fundoplication, to discard any primary motor esophageal disturbance.

Pharmacologic and non-pharmacologic methods are used in GERD to meet the therapeutic goals by decreasing gastroesophageal reflux, rendering the refluxate harmless, improving esophageal clearance and protecting the esophageal mucosa.

Surgical intervention is usually reserved for patients in whom medical treatment is ineffective. Ultimately, $5 \%$ of patients with GERD will require surgery. Indications include reflux related pulmonary disease, persistent ulcerative esophagitis, recurrent esophageal strictures and large hiatal hernia ${ }^{(16)}$.

Surgery may also be considered as an alternative to long-term proton pump inhibitors therapy for young patients with severe GERD, mainly when there is supine reflux at 24-h pHmetry or defective LES ${ }^{(4)}$.

Conventional reflux surgery, or fundoplication, has proven very effective. Because laparoscopic surgery is less traumatic, it is associated with less pain, fewer complications, a shorter hospital stay and a faster return to work.

Undoubtedly the introduction of laparoscopic techniques has led to a significant greater number of laparoscopic antireflux procedures.

There are yet controversies about the necessity of division of the short gastric vessels and full mobilization of the gastric fundus to perform an adequate fundoplication ${ }^{(8,20)}$.

\section{PATIENTS AND METHODS}

Fourteen patients (eight women, six men) were operated consecutively and prospectively. Their age range was 32 to 63 years (mean 44.07, standard deviation 7.86). All patients had symptomatic GERD (retrosternal pyrosis) and erosive esophagitis without Barrett's endoscopic signals (grade 3, Savary-Miller) and received medical treatment with proton pump inhibitors without permanent resolution of symptoms. The preoperative evaluation included detailed history, upper gastrointestinal endoscopy, esophageal manometry and 24-pH monitoring.

Esophageal manometry was done using 6-channel (4-radial) water perfused catheter system connected to the Synectics Polygram after an overnight fast. Esophageal body motility was evaluated with wet swallows and all the patients were considered normal on this aspect (peristaltic waves with amplitude of the contractions being greater than $60 \mathrm{~mm} \mathrm{Hg}$ in the distal esophagus).

The lower esophageal sphincter was studied by station pullthrough technique, with the catheter withdrawn at $0.5 \mathrm{~cm}$ intervals.

Proton pump inhibitors were stopped 5 days before the study and, after the completion of the manometric study, the $\mathrm{pH}$ probe was inserted with the tip $5 \mathrm{~cm}$ above the LES and recording was done for a 24-h period using the Medtronics Functional Diagnostics Digitrapper Mark III. Data were used to calculate the DeMeester score.

The Rossetti modification of the Nissen fundoplication ${ }^{(15)}$ was performed in all patients, by videolaparoscopic approach, under general anesthesia.

The phrenoesophageal membrane is opened and the terminal esophagus and cardia are exposed.

The hiatus is sutured (narrowed to the esophagus caliber more $2 \mathrm{~cm}$ ) and after split the gastrophrenic ligament and posterior dissection of the convexity of the fundus, the anterior fundic wall is passed behind the esophagus.

It was never done short gastric vessels division and there was ever sufficiently mobile fundus to perform a floppy fundoplication. The gastrohepatic ligament is left intact.

Four seromuscular sutures are placed between the fundus wrap and esophageal anterior wall. The width of the wrap was tested, and its extension was at least $4 \mathrm{~cm}$.

Follow-up was done until around 18 months (14-22 months) postoperatively; the patients were asked about recurrence of pyrosis, difficulty swallowing period, whether they were using proton pump inhibitors again and at the latest evaluation they were submitted to the same exams of the preoperative period (the protocol was exhibited to all of them previously with absolute voluntary acceptance) and the results were compared to the preoperative data, with $t$ test analysis.

\section{RESULTS}

\section{Preoperative period}

LES had range of extension between 2.5 and $4.5 \mathrm{~cm}$ (average, 3.17 and standard deviation, 0.6) and of pressure between 4 and 
$8.5 \mathrm{~mm} \mathrm{Hg}$ (average, 5.82, standard deviation, 1.13) and relaxing pressure between 0.1 and $1 \mathrm{~mm} \mathrm{Hg}$ (average, 0.38 and standard deviation, 0.26).

De Meester score range was 12.3 to 24.5 , average, 16.75 and standard deviation, 3.87 .

\section{Surgical procedure}

Operative time was around 75 minutes (55-115 minutes), without conversions. Regular diet was given after 1 week. The patients were discharged 2 days after operation, without morbidity.

\section{Postoperative period}

All patients at follow-up noticed marked improvement of preoperative symptoms; transient dysphagia period ranged between 12 and 43 days (average, 18.42 and standard deviation, 8.74); only one had to use antacids occasionally for relief of light thoracic discomfort.

This patient revealed a light esophagitis (grade 1, Savary-Miller) at endoscopy; all the others presented normal endoscopic view of the distal esophagus. There was no register of dehiscence or displacement of the fundoplication.

The postoperative eletromanometric results showed LES pressure range between 10 and $14 \mathrm{~mm} \mathrm{Hg}$ (average, $12 \mathrm{~mm} \mathrm{Hg}$ and standard deviation, 1.3) and relaxing pressure between 4.3 and 5.9 $\mathrm{mm} \mathrm{Hg}$ (average, 5.24 and standard deviation, 0.51), without any modification of its extension and of motor pattern of esophageal body.

The 24-h pHmetry revealed a DeMeester score range between 0 and 3 (average, 0.8 and standard deviation, 0.9).

The Figures 1, 2, 3 summarizes the preoperative and postoperative data and the application of the $t$ test.

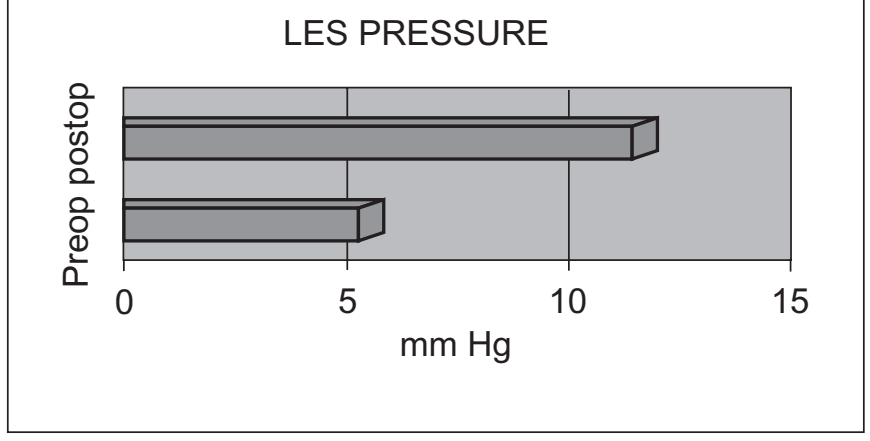

FIGURE 1 - LES pressure in pre and postoperative period $(P<0.01)$

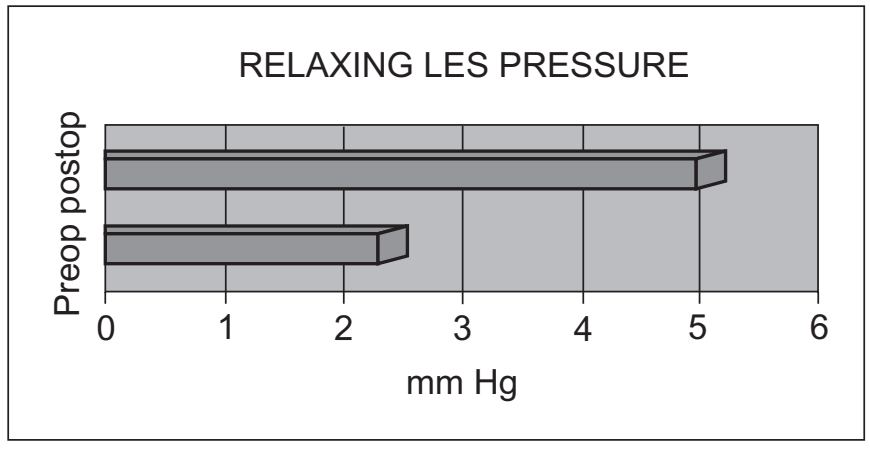

FIGURE 2 - Relaxing LES pressure in pre and postoperative period $(P<0.01)$

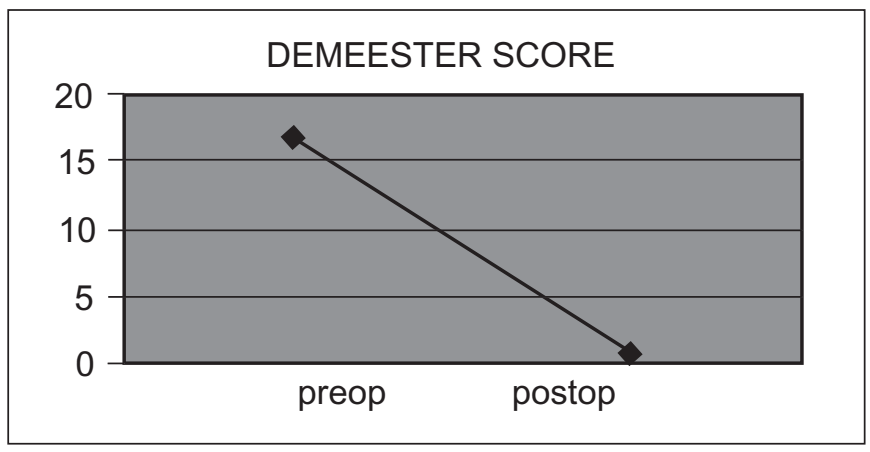

FIGURE 3 - DeMeester score in pre and postoperative period $(P<0.01)$

\section{DISCUSSION}

Today laparoscopic antireflux surgery conquers the world.

The Rossetti procedure, without gastric vessels section, seems a more simple and secure procedure for a non-complicated case of GERD, without fibrosis, periesophagitis and brachyesophagus.

Anatomic studies of LIEBBERMANN-MEFFERT ${ }^{(12)}$ and experimental and clinical functional studies about function of fundoplication $^{(6,17)}$ reinforce the role of this type of operation in treatment of reflux and incompetence of the LES. The fundus muscular fiber arrangement after fundoplication, in the same disposition as that of LES, and the hormone similar sensibility of them encourage towards clinical application of this type of operation, recommended after careful clinical and technical diagnosis and unsuccessful medical treatment.

The design of the study included $24 \mathrm{~h}$ pHmetry and manometric test, but in clinical practice, the Brazilian Consensus on Gastroesophageal Reflux Disease ${ }^{(14)}$ concluded:

1. twenty-four-hour $\mathrm{pH}$ recordings are indicated in the following situations:

- patients with typical symptoms of GERD and endoscopic esophagitis who do not respond satisfactorily to proton pump inhibitors; 
- $\quad$ patients with atypical manifestations such as non-cardiac thoracic pain or extra-esophageal manifestations;

- when esophagitis was not demonstrated in a preoperative endoscopic examination;

2. Esophageal manometry has limited indications in GERD:

- investigation of esophageal motility must be considered in dysphagic patients to discard achalasia and scleroderma and to avoid surgery or undergo an alternative procedure;

- determine the precise location of the lower esophageal sphincter to permit accurate placement of a $\mathrm{pH}$ electrode.

With a floppy fundoplication really tested in the operation, postoperative transient dysphagia is common and not a consistent problem nor due to altered peristalsis ${ }^{(19)}$ the results of this study proved it. Maybe an adaptive period to the new relaxing pressure of the LES could contribute to the symptom.

According to the international ${ }^{(5)}$ and Brazilian ${ }^{(2,21)}$ literature, the short follow-up of the fundoplication has excellent clinical and endoscopic results, also when the technique is applied without gastric vessels section.

WATSON et al. ${ }^{(20)}$ demonstrated in a prospective randomized trial of laparoscopic Nissen fundoplication with division and without division of short gastric vessels that this step did not improve any clinical or objective postoperative outcome.
Anatomic study ${ }^{(1)}$ showed that the posterior dissection provides sufficient length to the gastric fundus to perform a floppy fundoplication, avoiding necessity of short gastric vessels division.

By other side, LUOSTARINEN and ISOLAURI ${ }^{(13)}$ suggested that fundic excessive mobilization did not give any apparent advantage regarding postoperative adverse effects. Instead, it was associated with a higher rate of recurrent hiatal hernia, due to facilitate sliding effect of the esophagogastric junction with the plicature.

The results of the manometric study and of the 24-h pHmetry justify our preference, employing the Rossetti technique for the surgical treatment of gastroesophageal reflux, as LEVY et al. ${ }^{(11)}$ in their pediatric patients.

Increase of the LES pressure and LES relaxing pressure transfers confiability to the method.

Del GENIO et al. ${ }^{(3)}$ also verified LES pressure increase after total fundoplication in surgical treatment of GERD and since SPECHLER related $^{(18)}$ the normalization of DeMeester score occurs after an adequate fundoplication.

Thus we can conclude that the Rossetti procedure is an effective surgical method to treat GERD and that for a non complicated case of GERD gastric vessels section is unnecessary to perform an adequate fundoplication.

Felix VN, Yogi I, Perini M, Echeverria R, Bernardi C. Tratamento cirúrgico do refluxo gastroesofagiano não-complicado. Fundoplicatura sem secção dos vasos gástricos curtos. Arq Gastroenterol 2002;39(2)93-97.

RESUMO - Racional - Há hoje grande número de propostas para o tratamento cirúrgico da doença do refluxo gastroesofagiano e persistem controvérsias a respeito da necessidade da secção dos vasos gástricos curtos e ampla mobilização do fundo gástrico para realizar adequada fundoplicatura. Objetivo - Verificar os resultados da aplicação da modificação de Rossetti para a técnica de Nissen, no tratamento cirúrgico da doença do refluxo gastroesofágico não-complicada. Método - Catorze pacientes foram operados consecutiva e prospectivamente (média de idades de 44,07 anos); todos apresentavam esofagite erosiva sem sinais endoscópicos de Barrett (grau 3 de Savary-Miller) e foram submetidos a fundoplicatura de Nissen com modificação de Rossetti. Endoscopia, eletromanometria e pHmetria foram realizadas antes do procedimento e com cerca de 18 meses de pós-operatório. Resultados - Não houve morbidade, a disfagia transitória foi, em média, de 18,42 dias; não houve casos de deiscência ou migração da fundoplicatura e apenas um paciente revelou esofagite (leve) à endoscopia pós-operatória, os demais apresentando aspecto normal da mucosa do esôfago distal. Todos referiram grande melhora dos sintomas pré-operatórios. A pressão de repouso do esfíncter inferior do esôfago, de $5,82 \mathrm{~mm} \mathrm{Hg}$ no pré-operatório em média, passou a $12 \mathrm{~mm} \mathrm{Hg}$ no pós-operatório; a pressão de relaxamento do esfíncter inferior do esôfago passou de $0,38 \mathrm{~mm} \mathrm{Hg}$ a $5,24 \mathrm{~mm} \mathrm{Hg}$ e o índice de DeMeester, de 16,75 a 0,8. Conclusão - O procedimento de Rossetti (fundoplicatura sem secção prévia dos vasos gástricos curtos) é método cirúrgico efetivo para tratamento da doença do refluxo gastroesofagiano.

DESCRITORES - Refluxo gastroesofágico, cirurgia. Junção esofagogástrica, cirurgia. Fundoplicatura.

\section{REFERENCES}

1. Brandalise A, Munhoz AM, Brandalise NA. A gastrofundoplicatura laparoscópica: a importância da liberação do fundo gástrico. GED Gastroenterol Endosc Dig 1995;14:213-5.

2. Coelho JCU, Wiederkehr JC, Campos ACL, Andrigheto PC, Pinho RV, Bonin EA. Complicações do tratamento laparoscópico da doença do refluxo gastroesofágico. Experiência com 600 casos. Rev Col Bras Cir 1999;26:23742.

3. Del Genio A, Izzo G, Di Martino N, Maffettone V, Landolfi V, Martella A, Barbato D. Intraoperative esophageal manometry: our experience. Dis Esophagus 1997; 10:253-61.

4. DeMeester TR, Bonavina L, Albertucci M. Nissen fundoplication for gastroesophageal reflux disease. Ann Surg 1986;204:9-20.
5. Donahue PE. Nissen fundoplication for gastroesophageal reflux: the floppy Nissen fundoplication - technique and results. Dis Esophagus 1996;9:258 62.

6. Felix VN. Fundogastropexy - the pentagastrin effect on the LES pressure in chagasic patients. ABCD Arq Bras Cir Dig 1987;2:96-7.

7. Felix VN, Viebig RG. Nutcracker esophagus: a primary motor disorder or a consequence of another esophageal disease? In: Esophagus 2001. VIIIth World Congress Proceedings; 2001 Sep; São Paulo, SP, Brazil. p.118.

8. Hinder RA, Smith SL, Klingler PJ, Branton AS, Floch NR, Seelig MH Laparoscopic antireflux surgery - It's a wrap! Dig Surg 1999;16:7-11.

9. Katz PO. Disorders of the esophagus: dysphagia, non-cardiac chest pain and gastroesophageal reflux. In: Barker LR, Burton JR, Zieve PD, editors. Principles of ambulatory medicine. Baltimore: Williams \& Wilkins; 1995. p.435-46.

10. Katz PO. Gastroesophageal reflux disease. J Am Geriatr Soc 1998;46:1558-65. 
Felix VN, Yogi I, Perini M, Echeverria R, Bernardi C. Surgical treatment of the non-complicated gastroesophageal reflux. Fundoplication without division of the short gastric vessels

11. Levy MS, Sorrels CW, Wagner CW, Jackson RJ, Barnes RW, Smith SD. Evolution of the modified Rossetti fundoplication in children: surgical technique and results. Ann Surg 1999;229:774-9.

12. Liebermann-Meffert D. Architeture of the musculature at the gastroesophageal junction and in the fundus. Chir Gastroenterol 1975;9:425-9.

13. Luostarinen ME, Isolauri JO. Randomized trial to study the effect of fundic mobilization on long-term results of Nissen fundoplication. Br J Surg 1999;86:614-8.

14. Moraes-Filho JPP, Cecconello I, Gama-Rodrigues JJ, Castro LP, Henry MA, Meneghelli UG, Quigley E, Brazilian Consensus Group. Brazilian consensus on gastroesophageal reflux disease: proposals for assessment, classification and management. Am J Gastroenterol 2002;97:241-8.

15. Rossetti ME, Liebermann-Meffert D, Brauer RB. Nissen fundoplication for gastroesophageal reflux disease: the Rossetti modification of the Nissen fundoplication - technique and results. Dis Esophagus 1996;9:251-7.

16. Scott M, Gelhot ART. Gastroesophageal reflux disease: diagnosis and management. Am Fam Physician 1999;59:1161-9.
17. Siewert JR, Jennewein HM, Waldeck F, Peiper HJ. Experimentelle und klinische Untersuchungen zum Wirkungsmechanismus der Fundoplicatio. Langenbecks Arch Klin Chir 1973;333:5-22.

18. Spechler SJ. Comparison of medical and surgical therapy for complicated gastroesophageal reflux disease in veterans. N Engl J Med 1992;326:786-92.

19. Tew S, Jamieson GG, Holloway RH, Ferguson S, Tew S. A prospective study of the effect of fundoplication on primary and secondary peristalsis in the esophagus. Dis Esophagus 1997; 10:247-52.

20. Watson DI, Jamieson GG, Pike GK, Davies N, Richardson M, Devitt PG. Prospective randomized double-blind trial between laparoscopic Nissen fundoplication and anterior partial fundoplication. Br J Surg 1999;86:123-30.

21. Zilberstein B, Ramos AC, Sallet JA, Engel FC, Tanikawa DYS Esofagofundogastroplicatura videolaparoscópica por técnica mista. Rev Col Bras Cir 1999;26:341-5.

Recebido em 6/2/2002. Aprovado em 20/5/2002. 